\title{
Pemanfaatan Pekarangan untuk Peningkatan Ketahanan Pangan di Desa Akar Akar Kabupaten Lombok Utara
}

\author{
Suwardji $i^{*}$ Caesario Susmadi $\mathbf{M}^{2}$, Annisa Suryanti ${ }^{2}$, Sopia Hidayati ${ }^{2}$, Nurul Putri $\mathbf{P}^{2}$, Sofia Dianti $\mathbf{Y}^{2}$, Rida \\ Olina $\mathbf{C}^{3}$, Maya Rizki $A^{3}$, Yudi Apriyan 3 , Alvin Janitera ${ }^{3}$, Mimi Atiatun $\mathbf{R}^{4}$, Anisah Resty $\mathbf{U}^{5}$, Muhammad \\ Khiorul $A^{5}$, M Thoriq Panji $A^{6}$ dan Feby Umaroh $I^{7}$ \\ 1 Jurusan Ilmu Tanah Fakultas Fakultas Pertanian, Universitas Mataram, Mataram, Indonesia. \\ ${ }^{2}$ Program Studi Ilmu Hukum, Fakultas Hukum, Universitas Mataram, Mataram, Indonesia; \\ ${ }^{3}$ Program Studi Manajemen, Fakultas Ekonomi dan Bisnis, Universitas Mataram, Mataram, Indonesia; \\ ${ }^{4}$ Program Studi Akuntansi, Fakultas Ekonomi dan Bisnis, Universitas Mataram, Mataram, Indonesia; \\ ${ }^{5}$ Program Studi Agribisnis, Fakultas Pertanian, Universitas Mataram, Mataram, Indonesia; \\ ${ }^{6}$ Program Studi Teknik Sipil, Fakultas Teknik, Universitas Mataram, Mataram, Indonesia; \\ ${ }^{7}$ Program Studi Ilmu Fisika, Fakultas Matematika dan Ilmu Pengetahuan Alam, Universitas Mataram, Mataram, Indonesia;
}

https://doi.org/10.29303/jpmpi.v3i2.949

Sitasi: Suwardji., Susmadi M, C., Suryanti, A., Hidayati, S., Putri P, N., Dianti Y, S., Olina C, R., Rizki A, M., Apriyan, Y., Janitera, A., Atiatun R, M., Resty U, A., Khoirul A, M., Panji A, M. T \& Umaroh I, F. (2021). Pemanfaatan Pekarangan untuk Peningkatan Ketahanan Pangan di Desa Akar Akar Kabupaten Lombok Utara. Jurnal Pengabdian Magister Pendidikan IPA, 4(3)

\section{Article history \\ Received: 28 Agustus 2021 \\ Revised: 11 September 2021 \\ Accepted: 13 September 2021 \\ *Corresponding Author: \\ Suwardji, Jurusan Ilmu \\ Tanah Fakultas Fakultas \\ Pertanian, Universitas \\ Mataram, Mataram, Indonesia \\ Email: suwardji@unram.ac.id}

\begin{abstract}
Pandemi Covid 19 yang terjadi di seluruh dunia berdampak pada berbagai aspek kehidupan yang sering dibutuhkan oleh masyarakat dunia, salah satunya adalah ketahanan pangan yang terjadi di Indonesia yang menjadi suatu hal yang sangat di antisipasi oleh warga, khusus nya yang berada disekitaran daerah atau lahan yang relatif kering yang membuat warga yang bertempat tinggal di daerah tersebut kesusahan untuk mencukupi kebutuhan pokok nya, seperti sayuran dan juga buah buahan yang termasuk dalam konsumsi pokok bagi warga, upaya untuk mengatasi hal tersebut yaitu dengan cara berbagi ilmu beserta pengalaman dengan para warga seperti metode penanaman dan juga cara ataupun terobosan baru lainya, salah satunya adalah metode penanaman hidroponik dengan menggunakan styrofoam sebagai media untuk penanaman tumbuhan sayuran dan lain lain, metode hidroponik ini sebenarnya banyak macam nya hanya saja dengan menggunakan media styrofoam ini diharapkan hal ini tidak banyak menguras biaya dan tentunya mudah untuk dipahami oleh warga ataupun masyarakat yang masih awam terhadap metode ini, terlebih lagi mulai dari bahan yang digunakan relatif mudah untuk didapatkan, dan juga hal ini bertujuan untuk tata cara menjadi peluang usaha baru bagi para warga dimana di masa pandemi seperti ini hampir sebagian pekerja mengalami PHK dan masyarakat lainya kehilangan pekerjaan sehari harinya.
\end{abstract}

Keywords: Hidroponik, Covid 19; Sayuran; Ketahanan Pangan.

\section{Pendahuluan}

Pandemi COVID-19 berdampak besar bagi perekonomian masyarakat, berdasarkan data pertumbuhan ekonomi Indonesia pada triwulan pertama di tahun 2020, terjadi penurunan sebesar
2,3\% dari tahun 2019, dan berdasarkan laporan data WHO terkait Covid 19 di Indonesia pasien positif Covid 19 terdaftar sebanyak 650.197 jiwa, korban meninggal 19.514 jiwa dan sembuh 531.995 jiwa (WHO,2021).

Didaerah NTB sendiri hingga 6 januari 2021 dilaporkan kasus positif sebanyak 5.961 jiwa, 777 pasien dalam perawatan, 4,889 pasien sembuh 
dan 295 pasien meninggal dunia (NTBProv, 2020), maka pandemic Covid 19 memiliki dampak besar bagi perekonomian masyarakat, dampak buruk yang ditimbulkan diantaranya kesulitan akan pengelolaan serta perkembangan usaha masyarakat, salah satunya upaya untuk mengatasi permasalahan tersebut ialah menumbuhkan motivasi memulai bisnis baru, contoh nya mengaplikasikan metode penanaman hidroponik dengan media Styrofoam, yang dimana hal ini dapat menjadi lahan bisnis baru dan dapat membantu kehidupan masyarakat yang terdampak akan pandemi covid 19, selain murah metode ini sangat mudah dipahami bagi individual maupun kelompok yang memang masih sangat awam dengan sector pertanian.

\section{Metode}

Alat alat yang diperlukan yaitu Styrofoam Buah/Kecil, Bibit tanaman, Rockwool, Net Pot, $\mathrm{Ph}$ Meter, Nutrisi AB Mix, Gunting, Cutter, Kain Flannel, Plastik. Proses dimulai dengan menyemai terlebih dahulu bibit tanaman sayuran yang telah disiapkan kemudian sembari menunggu proses penyemaian, bisa sambil melakukan pemotongan rockwool, kemudian dibagi menjadi beberapa bagian serta bisa disesuaikan dengan jumlah bibit yang telah disemai kemudian letak kan ke rockwool yang telah diberikan lubang pada rockwool tersebut, setelah berjalan 4-5 hari waktu penyemaian barulah bibit yang telah disemai dipindahkan ke netpot yang seterusnya ditempatkan dimedia tanam (styorofoam) yang telah ditambahkan dengan kain flannel tersebut, barulah siapkan net pot dan sesuaikan dengan jumlah dari bibit yang telah disemai tadi, kemudian setelah berusia seminggu atau setelah tumbuh 3 helai barulah dipindahkan ke Styrofoam, tetapi sebelum dipindahkan Styrofoam tersebut terlebih dahulu diisi dengan air secukupnya dan tidak lupa diukur terlebih dahulu menggunakan $\mathrm{Ph}$ Meter barulah ditambahkan dengan nutrisi $\mathrm{AB}$ Mix yang dilarutkan terlebih dahulu dari dalam bentuk bubuk, ke bentuk cair, dan dicampurkan dengan air yang telah diisi di dalam Styrofoam, sehingga Langkah selanjutnya adalah meletakan net pot yang telah diisi dengan bibit yang telah disemai tadi ke lubang yang berada di tutup Styrofoam dan tutup Styrofoam tersebut diletakan Kembali bagian Styrofoam yang telah diisi dengan air yang sudah dicampur dengan nutrisi.
Sisanya adalah menunggu bibit tadi tumbuh dan masuk pada masa panen, yang diharapkan bisa menjadi sebuah lapangan usaha baru dan menjadi opsi kegiatan bagi warga, khusus nya pada ibu rumah tangga dan ibu pkk, selain itu tidak salah nya juga untuk menjadi lapangan pekerjaan serta Langkah utama bagi para petani muda untuk terjun kedalam dunia pertanian sembari mengumpulkan pengalaman dan juga mengasah skill dasar dalam bertani, terlebih lagi mayoritas pekerjaan warga di Desa Akar Akar Kecamatan Bayan Kabupaten Lombok Utara memang sebagai petani, namun berbeda jika musim hujan telah datang, Sebagian beralih profesi ke nelayan hanya pada saat musim hujan, dan Kembali lagi sebagai petani setelah musim hujan berakhir, maka dari itu metode hidroponik serta media yang kami coba sampaikan serta bagikan ke warga ini bisa jadi terobosan serta Langkah utama bagi para remaja muda mudi di sekitar Desa Akar Akar untuk terjun ke dalam Dunia Pertanian.

Metode Hidroponik dengan menggunakan media Styrofoam ini merupakan salah satu tata cara penanaman yang ada, yang ditujukan tidak hanya untuk masyarakat yang terdampak pada pandemi, namun juga untuk warga ataupun masyarakat yang mengalami krisis pada sector Ketahanan Pangan, khusus nya untuk tanaman sayuran, yang dimana dapat dikatakan sangat cocok untuk metode penanaman ini, dan juga diharapkan dapat mendukung dunia pertanian bagi para petani muda, dan dapat memberikan kesan kedepanya bahwa memiliki profesi sebagai petani itu sangatlah menjanjikan dan tentunya modern dengan terus update dengan metode dan juga tata cara Bertani yang dinamis serta terus berkembang seiring zaman.

Pembuatan serta alur dalam mengaplikasikan metode hidroponik ini terbilang mudah karena bahan bahan utama seperti Styrofoam, net pot, bibit tanaman, rockwool dan lainya sangatlah mudah untuk dijumpai, dan apabila tidak dapat menemui bahan bahan tersebut, hal itu tentu memilik bahan alternatif, seperti net pot dapat digantikan dengan gelar air mineral, kemudian rockwool dapat digantikan dengan kapas ataupun spons cuci piring, bahan bahan tersebut dapat ditemukan dengan mudah di Lombok Utara yang bisa diajak sebagai salah satu mitra kerja sama, selain itu proses penyemaian bibit yang relative mudah akan sangat terbantu dengan sumber daya 
manusia yang sangat antusias serta kreatif dalam proses ini, dan tidak hanya dalam metode hidroponik ini, namun dalam hal lainya warga serta masyarakat sangat mendukung untuk kegiatan yang coba untuk diterapkan.

\section{Hasil dan Pembahasan}

Ketahanan pangan adalah ketersediaan pangan dan kemampuan seseorang ataupun kelompok untuk dapat mengakses nya, sebuah rumah tangga dapat dikatakan memiliki ketahanan pangan jika penghuninya tidak berada dalam kondisi kelaparan atau dihantui oleh ancaman kelaparan, maka dengan hal itu dengan ini kami mencoba memperkenalkan salah satu variant dari metode hidroponik yaitu metode penanaman yang mungkin bagi Sebagian atau segelintir orang masih awam mendengar nya, atau mungkin mereka sudah pernah mendengar nya, tetapi belum memahami secara konsep dan alur untuk menerapkan nya langsung.

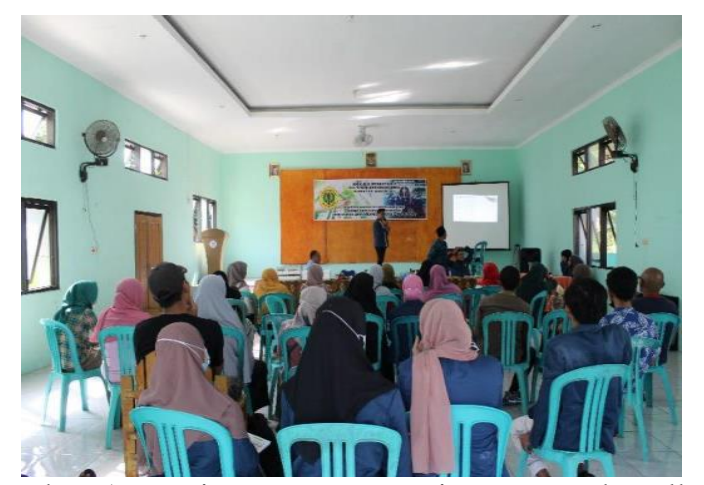

Gambar 1. Kegiatan pertama yaitu memperkenalkan metode ini secara teori, yaitu melalui sosialisasi yang kami adakan sekaligus memaparkan program kerja apa saja yang akan kami terapkan selama berada di Desa Akar Akar.

Sembari Mensosialisasikan Program kerja utama dan tambahan, di penghujung acara kami juga memaparkan bahan bahan yang akan dibutuhkan untuk digunakan dalam memproses metode penanaman hidroponik dengan Styrofoam selaku Program Utama kami, mulai dari bibit, cutter, kain flannel, serta nutrisi yang akan digunakan dalam pertumbuhan dari bibit yang telah disemai tersebut, kami coba paparkan dan beri informasi kepada warga dan tidak lupa juga beserta bahan alternatif nya yang apabila warga setempat kesusahan untuk menjumpai bahan utama nya masih memiliki alternatif lain untuk tetap menjalankan metode hidroponik ini.

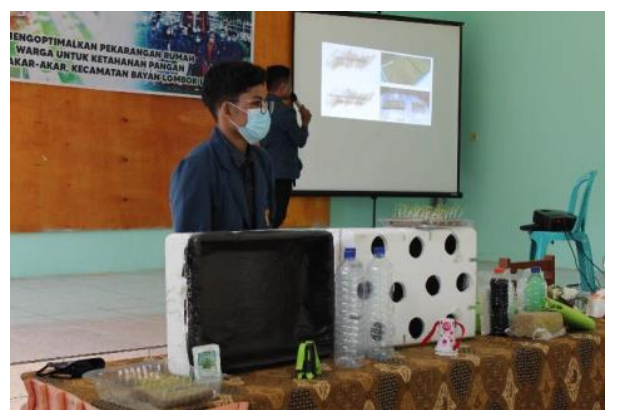

Gambar 2. net pot yang sudah dipasangi dengan kain flannel yang telah dipotong, dan juga Styrofoam yang telah dipasangkan plastik untuk mencegah air keluar Ketika telah di isi air beserta nutrisi nya nanti

Setelah memaparkan Program kami dan juga bahan yang akan digunakan untuk menerapkan metode hidroponik dengan media styrofoam tersebut, di keesokan harinya kami langsung coba untuk mempraktekan bersama warga di setiap dusun nya, untuk memberikan pengalaman langsung kepada warga dan tidak sebatas mendengarkan dan mendapatkan secara teori saja, Setelah melakukan proses penyemaian serta memindahkan bibit ke styrofoam, sisanya adalah melakukan kegiatan untuk mengkontrol setiap harinya dari perkembangan tanaman tersebut, seperti mengecek keadaan tanaman, dan juga keadaan air yang sudah dicampur dengan nutrisi yang berada di dalam styrofoam yang apabila dirasa kurang maka dapat ditambahkan secukupnya, pada tahap ini diharapkan untuk tetap melakukan nya setiap hari dan butuh kesabaran hingga pada hari ke 21 atau lebih, dirasa sudah mulai masuk pada masa panen.

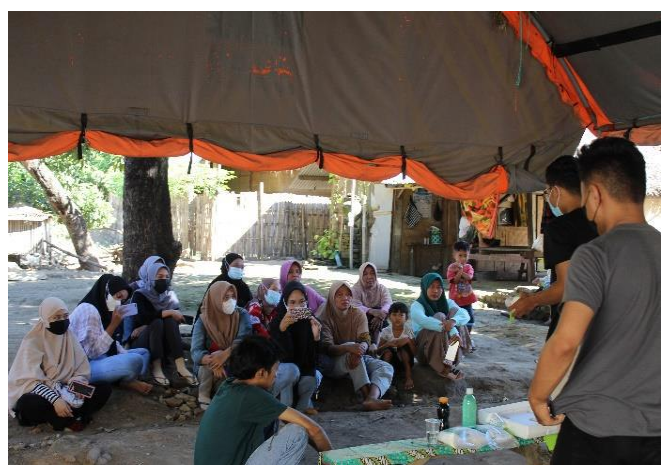

Gambar 3. Mempraktekan secara langsung bersama warga terkait metode hidroponik dengan media styrofoam mulai dari proses penyemaian hingga meletakan bibit yang telah disemai ke Styrofoam. 


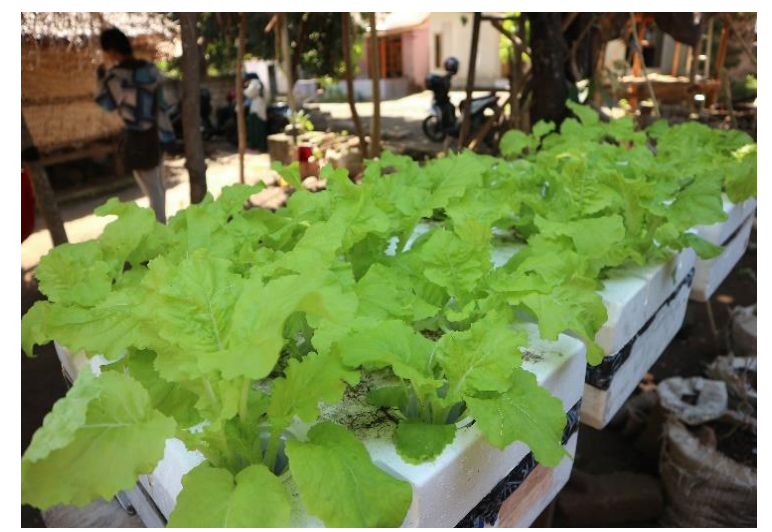

Gambar 4. Contoh tanaman ketika sudah berusia 3 minggu 1 hari dan sudah memasuki masa panen.

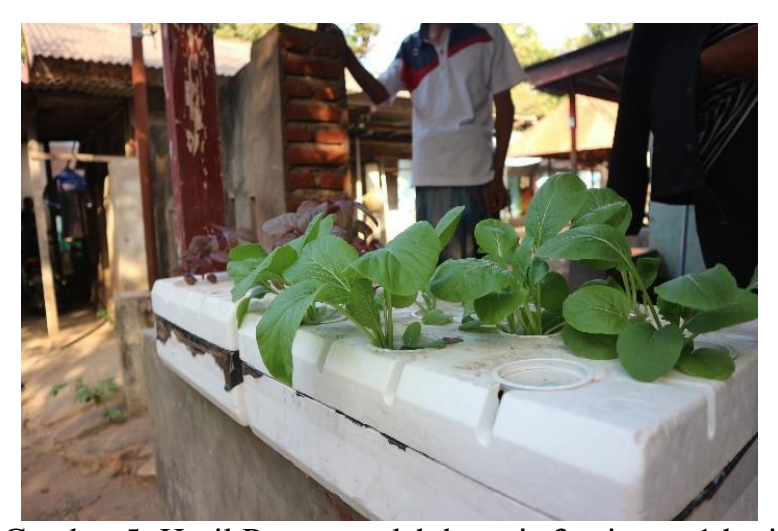

Gambar 5. Hasil Panen setelah berusia 3 minggu 1 hari di salah satu Dusun Desa Akar Akar yang menjadi target dari Program Metode Hidroponik dengan media Styrofoam.

\section{Kesimpulan}

Metode Hidroponik sangatlah luas, namun yang coba kami tawarkan pada warga setempat relatif menjadi salah satu yang paling mudah dan tidak banyak menghabiskan biaya, dan tentunya dapat dengan mudah dipahami oleh masyarakat yang awam akan dunia pertanian, dan juga metode ini bisa menjadi salah satu usaha yang tentunya dapat dikembangkan terlebih lagi bagi para petani muda dan juga dengan kondisi sekarang yang sangat krisis akan nilai ekonomi dikarenakan Pandemi Covid 19.

\section{Ucapan Terima Kasih}

Ucapan terimakasih kami kepada Bapak Prof. Ir. Suwardji, M.App. Sc., Ph.D. selaku pembimbing atau Dosen pembimbing lapangan kami selama melaksanakan kegiatan KKN, yang telah memberikan arahan dari awal membentuk seluruh program yang akan di terapkan selama masa KKN, hingga penyusunan Laporan, Artikel, dan kebutuhan lainya untuk mendapatkan hasil Semaksimal mungkin.

\section{Daftar Pustaka}

Nurdin SQ., (2017). Agro Media Pustaka. Mempercepat Panen Sayuran Hidroponik

Pinus Lingga. (1984). Penebar Swadaya. Hidroponik Bercocok Tanam Tanpa Tanah

Roidah, I. (2014). Pemanfaatan Lahan Dengan Menggunakan Sistem Hidroponik. Jurnal Universitas Tulungagung Bonorowo. 1(2). Tallei, T., Rumengan, I., Adam, A. 2017. Hidroponik Untuk Pemula. Manado: UNSRAT Press.

Teguh Sutanto. (2015). Bibit Publisher. Rahasia Sukses Budidaya Tanaman dengan Metode Hidroponik 